\title{
Assessment of cadmium ion adsorption capacity in water by biochar produced from pyrolysis of cow dung
}

\author{
Nguyen Van Phuong ${ }^{1}$,Nguyen Khanh Hoang ${ }^{2}$ \\ ${ }^{1}$ Institute for Environmental Science, Engineering and Management, Industrial University of Ho Chi Minh City, Viet Nam, \\ nvphccb@gmail.com (Fist author) \\ ${ }^{2}$ Institute for Environmental Science, Engineering and Management, Industrial University of Ho Chi Minh City, Viet Nam \\ nguyenkhanhhoang@iuh.edu.vn (Corresponding author)
}

\begin{abstract}
Biochar production from cattle waste and the potential of biochar as an adsorbent for treating pollution are among the hot research topics in recent years. The goal of this study is to evaluate the ability to adsorption $\mathrm{Cd}^{2+}$ from water of biochar produced from cow dung at varying pyrolysis temperatures $\left(300,450\right.$, and $\left.500^{\circ} \mathrm{C}\right)$. The study determineda number of surface-level chemical characteristics of the biocharsamples such astotal organic carbon (TOC), $\mathrm{pH}, \mathrm{pH}_{\mathrm{pzc}}$, functional group $\mathrm{H}^{+}, \mathrm{OH}^{2}$, and cation exchange capacity (CEC). Biochar samples were subjected to two different experiments: the first submerged the biochar in $\mathrm{Cd}^{2+}$ solutions at different concentration $(0-$ $\left.132 \mathrm{mgCd}^{2+} \cdot \mathrm{L}^{-1}\right)$ for a fixed $12 \mathrm{~h}$ and the second submerged the biochar in $\mathrm{Cd}^{2+}$ solutions at a fixed concentration of $66 \mathrm{mgCd}^{2+} \cdot \mathrm{L}^{-1}$ for a varying length of time. Adsorption kinetics and equilibrium analyses were conducted on the samples at the end of the experiments. The $\mathrm{Cd}^{2+}$ adsorption process of these biochar forms fit Langmuir and Freundlich adsorption models as well as a pseudo-second-order kinetic model. The study concluded that biochar produced from pyrolysis of cow dung could be employed as an adsorbentfor the removal of $\mathrm{Cd}^{2+}$ from water.
\end{abstract}

Key words : adsorption kinetics, biochar, $\mathrm{Cd}^{2+}$,equilibrium, cow dung

\section{INTRODUCTION}

The detrimental effect of heavy metals and their compounds on aquaculture and people is a great concern in environmental research circles in recent years[1]. Among these metals, $\mathrm{Cd}$ is an element commonly found in wastewater from mining, metallurgy, electro-coating, and oil-refining industries[2]. While extraneous in nature, $\mathrm{Cd}$ is a carcinogen to bioforms even at low concentrations and, therefore, an effective and economical solution to remove $\mathrm{Cd}^{2+}$ from water is of utmost urgency. A number of techniques have been developed to tackle this issue including chemical precipitation, membrane filtration, ion exchange and adsorption[3].

Among them, adsorption is a popular choice to remove $\mathrm{Cd}^{2+}$ from wastewater[2]. Furthermore, adsorption using biochar is considered advantageous in terms of environmental friendliness and cost as biochar is widely available in large quantities[2]. Biochar is produced from agricultural byproduct via anaerobic pyrolysis at temperatures above $300^{\circ} \mathrm{C}$. Studies into adsorption mechanics have shown that a number of surface-level characteristics heavily influenced the adsorption efficacy of biochar. These characteristics of biochar are heavily influenced by the conditions of the pyrolysis process such as temperature and processing duration[1]. Nowadays, researches on biochar originating from cow dung, a main ranching byproduct in $\mathrm{Cu}$ Chi Distrist (Ho Chi Minh City), in this particular application remain few and far between. Therefore, the goal of this study is to survey the influence of pyrolysis temperature on the efficiency of biochar production and the influence of surface-level characteristics on the $\mathrm{Cd}^{2+}$ adsorption kinetics of biochar. In addition, the effects of the application of biochar to remove $\mathrm{Cd}^{2+}$ pollution in water werealso assessed.

\section{MATERIALSAND METHODS}

\section{Materials}

Cow dung samples were taken in a cow farm in $\mathrm{Cu}$ Chi Distrist, Ho Chi Minh City (Vietnam). The location of the sampling site is $1058^{\prime} 17,8^{\prime \prime} \mathrm{N}$; $10634^{\prime} 29,8^{\prime \prime} \mathrm{E}$. The samples were letto dry out andwere cut into smaller portions under $5 \mathrm{~mm}$. They were thenbaked in an oven at $60^{\circ} \mathrm{C}$ for $24 \mathrm{~h}[4]$.

\section{Chemicals}

All chemicals used in the study were of analytical-grade (Merck) including $\mathrm{Cd}\left(\mathrm{NO}_{3}\right)_{2} \cdot 4 \mathrm{H}_{2} \mathrm{O}, \mathrm{KCl}, \mathrm{HNO}_{3}, \mathrm{NaOH}$, $\mathrm{H}_{2} \mathrm{O}_{2}$. Aqueous solutions of $\mathrm{Cd}^{2+}$ were prepared as a stock solution at $1000 \mathrm{mg} \mathrm{Cd}^{2+} \cdot \mathrm{L}^{-1}$. Distilled water used in the experimentswas produced with an ultra-clean water purifier Model: EASYpure II RF from Thermo Scientific USA.

\section{Experiment procedure}

The prepared cow dung samples underwent the pyrolysis in a Nabertherm P330 furnace with the following temperature settings: 300,450 , and $600^{\circ} \mathrm{C}$ (temperature is set depending on the running experiment). The heating rate was set to $10^{\circ} \mathrm{C} \cdot \mathrm{min}^{-1}$. Once the desired temperature was reached, the temperature was kept constant for $2 \mathrm{~h}$ and the samples werelet to cool in the oven overnight. The biochar was then pressed through a plastic sieve (hole diameter of $1 \mathrm{~mm}$ ) to make homogeneous and were stored separately in polyethylene (PE) containers in dark at $4^{\circ} \mathrm{C}[5]$. 
Analyses were conducted on these biochar samples to determine surface-level characteristics such as $\mathrm{pH}$, $\mathrm{pH}_{\mathrm{pzc}}[6]$. Total organic carbon (TOC)[7], functional group $\mathrm{H}^{+}, \mathrm{OH}^{-}[8]$ and cation exchange capacity (CEC) based on [9]. These biochar samples were also employed in subsequent adsorption kinetics and adsorption equilibrium surveys.

The survey on the $\mathrm{Cd}^{2+}$ adsorption equilibrium of biochar was conducted based on a study of[10]. The experiment was performed in $60 \mathrm{~mL}$ polypropylene tubes containing a mixture of $0.25 \mathrm{~g}$ biochar and $25 \mathrm{~mL}$ diluted $\mathrm{Cd}^{2+}$ solution. The diluted $\mathrm{Cd}^{2+}$ solution was prepared by combining the $\mathrm{Cd}^{2+}$ stock solution (1000 mg. $\mathrm{L}^{-1}$ ) with $\mathrm{KCl} 0.01 \mathrm{M}$ solution. The concentration of thediluted $\mathrm{Cd}^{2+}$ solution varied between $0-132 \mathrm{mg} . \mathrm{L}^{-1}$ depending on the running experiment.A GFL3015 shaker was employed to agitate the polypropylene tube at $100 \mathrm{rpm}$ for $12 \mathrm{~h}$, which is the time to reach $\mathrm{Cd}^{2+}$ adsorption equilibrium at room temperature based on preliminary experiments. The $\mathrm{pH}$ level was not adjusted during this experiment ranges from 5.0-5.5 during this experiment. The solid settlement was separated from the mixture by a DLAB DM0636 centrifuge at $4000 \mathrm{rpm}$ for $15 \mathrm{~min}$. Then, the remaining solution was filtered through a $0.22 \mu \mathrm{m}$ filter andwas immediately acidified to $\mathrm{pH}<2$ using concentrated $\mathrm{HNO}_{3}$ in preparation for a $\mathrm{Cd}^{2+}$ analysis. by ICP-OES

Calculation of biochar recovery efficiency $\% \mathrm{H}$ :

$$
\% \mathrm{H}=\frac{m_{b}}{m_{0}} * 100
$$

Where:

$m_{0}(\mathrm{~g})$ : initial amount of cow dung before pyrolysis

$m_{b}(g)$ : amount of biochar recovered after pyrolysis

\section{Calculation of the biochar's $\mathrm{pH}_{\mathrm{pzc}}$ :}

$$
\Delta \mathrm{pH}=\left(p H_{\mathrm{f}}-\mathrm{p} H_{i}\right)
$$

Where:

$\mathrm{pH}_{\mathrm{i}}$ initial $\mathrm{pH}$ value

$\mathrm{pH}_{\mathrm{f}}: \mathrm{pH}$ value after biochar is added to the $0.01 \mathrm{M} \mathrm{KCl}$ solution

The value $\mathrm{pH}_{\mathrm{pzc}}$ was determined at the point where the plot $\Delta \mathrm{pH}_{\mathrm{pH}} \mathrm{p}_{\mathrm{i}}{ }^{1}$ intersected the line $\Delta \mathrm{pH}=0[6]$.

Calculation of the maximum adsorption capacity at equilibrium $q_{0}$ :

$$
q_{i}=\frac{\left(C_{0}-C_{i}\right) \cdot V}{\mathrm{~m}}
$$

Where:

$$
\begin{aligned}
& \mathrm{C}_{0}\left(\mathrm{mg}^{\mathrm{L}} \mathrm{L}^{-1}\right) \text { : concentration of initial } \mathrm{Cd}^{2+} \\
& \text { solution } \\
& \mathrm{C}_{\mathrm{i}}\left(\mathrm{mg}^{-} \mathrm{L}^{-1}\right) \text { : concentration of } \mathrm{Cd}^{2+} \text { solution } \\
& \text { of sample } \mathrm{i} \text { at equilibrium time } \\
& \mathrm{V}(\mathrm{L}): \text { volume of } \mathrm{Cd}^{2+} \text { solution } \\
& \mathrm{m}(\mathrm{g}): \text { mass of biochar } \\
& \mathrm{q}_{\mathrm{i}}\left(\mathrm{mg} \cdot \mathrm{g}^{-1}\right): \mathrm{Cd}^{2+} \text { adsorption capacity at equilibrium }
\end{aligned}
$$$$
\text { of sample } \mathrm{i}
$$

machine.Langmuir and Freundlich adsorption isotherms models were used in evaluating the suitability of experimental data[10].

The adsorption kinetics survey was similarly performed in $60 \mathrm{~mL}$ polypropylene tubes by mixing $0.25 \mathrm{~g}$ biochar with $25 \mathrm{~mL}$ of $0.01 \mathrm{M} \mathrm{KCl}$ solution containing $66 \mathrm{mg}^{-1} \mathrm{~L}^{-1} \mathrm{Cd}^{2+}$. They were also agitated by GFL3015 shaker at around 100 rpm. But, instead of a fixed $12 \mathrm{~h}$ as in the adsorption equilibrium survey, the duration of the agitation was taken at different times depending on the running experiment. The rest of the procedure followed as in the previous survey with the solid settlement being separated from the mixture by a DLAB DM0636 centrifuge (4000 rpm, 15 $\mathrm{min}$ ), the remaining solution being filtered through a $0.22 \mu \mathrm{m}$ filter before being acidified $(\mathrm{pH}<2)$ using concentrated $\mathrm{HNO}_{3}$ in preparation for a $\mathrm{Cd}^{2+}$ analysis by ICP-OES.Pseudo first- and second-order kinetic models were used in evaluating the suitability of experimental data and calculating the kinetic constants[10].

\section{Calculation}

The important parameters for the subsequent analyses were determined from the above experiments based on the formula and calculations described in this section.

The adsorption capacity $\mathrm{q}_{\mathrm{i}}$ above was then plugged into Langmuir adsorption isothermequationin order to calculate the maximum adsorption capacity $\mathrm{q}_{0}[11]$ :

$$
\frac{1}{q_{i}}=\frac{1}{K_{L} q_{0}} \frac{1}{C_{i}}+\frac{1}{q_{0}}
$$

Where:

$\mathrm{q}_{0}$ (mg.g-1): $\mathrm{Cd}^{2}+$ maximum adsorption capacity at equilibrium

$\mathrm{K}_{\mathrm{L}}\left(\mathrm{L} . \mathrm{mg}^{-1}\right)$ : Langmuir adsorption constant.

The above equation has the form of $y=a x+b$ and therefore could be solved by curve fitting $y=\frac{1}{q_{i}}$ and $x=\frac{1}{c_{i}}$ to yield $\mathrm{q}_{0}$.

The suitability of the adsorption isotherms was then evaluatedby comparing the result of Langmuir's model to that of Freundlichadsorption isotherm equation[11]

$$
q=y / m=K_{F} C^{\frac{1}{n_{F}}}
$$

Or:

$$
\log _{i}=\frac{1}{n_{F}} \log C_{i}+\log K_{F}
$$

Where:

$\mathrm{n}_{\mathrm{F}}: \quad$ Freundlich isotherm constant representing adsorption intensity ofCd ${ }^{2+}$. $\mathrm{K}_{\mathrm{F}}$ : Freundlich adsorbent constant representing adsorption capacity of $\mathrm{Cd}^{2+}$. This equation also has the form of $y=a x+b$ and as all the parameters are known, the plot of $\log _{i}$ against $\log C_{i}$ can be drawn. The shape of this plot is then compared to that drawn from experimental data. 
Calculation of adsorption kinetic coefficients: In order to evaluate the adsorption kinetic, the study employed pseudo first- and second-order models whose polynomial coefficients must be determined[11]. The models employed were the following:

Pseudo first-order kinetic equation:

$$
\operatorname{Ln}\left(q_{e}-q_{t}\right)-\operatorname{Ln} q_{e}=-k_{1} t
$$

Or:

$$
\operatorname{Ln}\left(q_{e}-q_{t}\right)=-k_{1} t+L n q_{e}
$$

Curve fitting $y=\operatorname{Ln}\left(q_{e}-q_{t}\right)$ and $x=t$ yields the coefficients for this model.

Pseudo second-order kinetic equation:

$$
\frac{1}{q_{t}}=\frac{1}{t} \frac{1}{k_{2} q_{e}^{2}}+\frac{1}{q_{e}}
$$

Where:

\section{RESULTS AND DISCUSSIONS}

\subsection{Effect of pyrolysis temperature on recovery efficiency and surface-level chemical characteristics of biochars}

The results showed that pyrolysis temperature has an effect on biochar recovery efficiency. Table 1 showed that whenthe temperature increases from 300 to 450 and $600^{\circ} \mathrm{C}$, the recovery efficiency of biocharsdecreasesto 63.0, 51.1, and 49.4\% $\mathrm{q}_{\mathrm{e}}$ : adsorption capacity at equilibrium (mg.g-1)

$\mathrm{q}_{\mathrm{t}}$ : the adsorption capacity at time $\mathrm{t}\left(\mathrm{mg} \cdot \mathrm{g}^{-1}\right)$

$\mathrm{k}_{1}\left(\mathrm{~min}^{-1}\right)$ và $\mathrm{k}_{2}\left(\mathrm{~g} \mathrm{mg}^{-1} \cdot \mathrm{min}^{-1}\right)$ : constants of pseudo first-order and pseudo second-order kinetic

$\mathrm{t}(\mathrm{min})$ : time adsorption.

Curve fittingy $=\frac{1}{q_{t}} \mathrm{and} x=\frac{1}{t}$ yields the necessary coefficients for this model.

\section{Statistical analysis}

Control and replicate samples $(n=3)$ were employed in order to minimize error sources. The analysis evaluatedthe accuracy and precision of the parameters calculated using the methods described in the previous section. The statistical analysis software SPSS 20.0 was used for determining the fitness of data through correlation test and for constructing a mathematical model through curve-fitting / regression. In addition, homogeneity was also evaluated by Levene's test, Tukey's test post hoc (Sig.>0.05) and Tamhane's T2 (Sig.<0.05)[12]. respectively. This isdue to the reduction of volatile substances in biochar[13]. The results are consistent with those from Yavari et al. (2016)who had reporteda decrease in recovery efficiency when pyrolysis temperature rises from 300 to $700^{\circ} \mathrm{C}[14]$. In their study, the recovery efficiency at $300^{\circ} \mathrm{C}$ is $59.5 \%$

\begin{tabular}{|c|c|c|c|c|c|c|c|}
\hline $\mathrm{t}^{\circ} \mathrm{C}$ & $\% \mathrm{H}$ & $\mathrm{pH}$ & pHpzc & $\mathrm{mmolH}^{+} \cdot \mathrm{g}^{-1}$ & mmolOH $\cdot g^{-1}$ & $\% \mathrm{TOC}$ & CEC. mmol.kg-1 \\
\hline 300 & $63 \pm 1.7 \mathrm{~b}$ & $7.91 \pm 0.03^{a}$ & $7.4 \pm 0.1^{a}$ & $5.1 \pm 0.1^{b}$ & $11.3 \pm 0.1^{\mathrm{a}}$ & $36.7 \pm 5.3^{b}$ & $113 \pm 12^{\mathrm{a}}$ \\
\hline 450 & $51.1 \pm 0.6^{a}$ & $9.34 \pm 0.03^{b}$ & $8.8 \pm 0.1^{b}$ & $4.4 \pm 0.3^{\mathrm{a} . \mathrm{b}}$ & $11.6 \pm 0.1^{b}$ & $61.2 \pm 0.5^{c}$ & $144 \pm 12^{b}$ \\
\hline 600 & $49.4 \pm 0.1 \mathrm{a}$ & $9.35 \pm 0.22 \mathrm{a} b$ & $9.1 \pm 0.1^{\mathrm{c}}$ & $3.7 \pm 0.2^{\mathrm{a}}$ & $12.4 \pm 0.2^{c}$ & $16.6 \pm 1.8^{a}$ & $188 \pm 12^{c}$ \\
\hline
\end{tabular}
and $37.9 \%$ at $700^{\circ} \mathrm{C}[14],[15]$.

Table1:Recovery efficiency and surface-level characterisics of biochars by pyrolysis temperature

Different letters in a column show a statistically significant difference $(\mathrm{p}<0.05)$

The results in Table 1 showed that the total organic carbon (TOC) content increased from $36.7 \%$ at $300^{\circ} \mathrm{C}$ to $61.2 \%$ at $450^{\circ} \mathrm{C}$. This is related to the production of organic acids and phenolic compounds due to thermal decomposition of cellulose and hemicelluloses compounds in the pyrolysis temperature range of the study Yavari et al., (2016)[14]. A sharp decrease of $16.6 \%$ was observed at $600^{\circ} \mathrm{C}$ and this is explained by products of the cellulose and lignin in biochar being completely decomposed in the temperature range of 280$500^{\circ} \mathrm{C}[14]$.

When the pyrolysis temperature increased from 300 to 450 and $600^{\circ} \mathrm{C}$, the $\mathrm{pH}$ level of biochar also increased from 7.9 to 9.34 and 9.35 , respectively. This is due to the partial transformation of organic matters intoashes, which releases alkali salts and increases the $\mathrm{pH}$ level of biochar[10].

The results also showed that pHpzc is proportional to pyrolysis temperature. pHpzcplays an important role in the choice of optimal $\mathrm{pH}$ level for adsorption experiments and reveals the adsorption kinetics. When the $\mathrm{pH}$ level in the test solution falls below pHpzc, the electrical potential on the surface of biochar becomes positive due to the protonization of acidic functional groups. This inhibits the adsorption of metals due to the pushing interactions between ions and functional groups[3]. On the other hand, precipitation takes place when the $\mathrm{pH}$ level rises above pHpzc. As the biochar samples produced from cow dung had $\mathrm{pH}$ level >pHpzc, they possessed negative electrical potential and heightened reactivity with metal ions[16]. 
Nguyen Van Phuong et al., International Journal of Emerging Trends in Engineering Research, 9(3), March 2021,203 - 210 Table2:Cross-correlation analysis of surface-level characteristics in biochar

\begin{tabular}{|c|c|c|c|c|c|c|c|c|}
\hline & $t^{\circ} \mathrm{C}$ & $\mathrm{pH}$ & pHpzc & $\mathrm{mmolH}^{+} \cdot \mathrm{g}^{-1}$ & $\underset{. \mathrm{g}^{-1}}{\mathrm{mmolOH}^{-}}$ & $\% \mathrm{H}$ & $\% \mathrm{TOC}$ & $\begin{array}{c}\text { CEC. } \\
\text { mmol.kg-1 }\end{array}$ \\
\hline $\mathrm{t}^{\circ} \mathrm{C}$ & 1 & $0.860^{* *}$ & $0.920^{* * 2}$ & $-0.953^{* * *}$ & $0.942^{* * *}$ & $-0.908^{* * *}$ & -0.445 & $0.946^{* * 2}$ \\
\hline $\mathrm{pH}$ & $0.860^{* *}$ & 1 & $0.979^{* *}$ & $-0.815^{* *}$ & 0.666 & $-0.973^{* *}$ & 0.057 & $0.745^{*}$ \\
\hline pHpzc & $0.920^{* *}$ & $0.979^{* *}$ & 1 & $-0.905^{* * *}$ & $0.744^{*}$ & $-0.992^{* *}$ & -0.066 & $0.820^{* *}$ \\
\hline $\mathrm{mmolH}^{+} \cdot \mathrm{g}^{-1}$ & $-0.953^{* *}$ & $-0.815^{* *}$ & $-0.905^{* *}$ & 1 & $-0.865^{* *}$ & $0.885^{* *}$ & 0.384 & $-0.867^{* *}$ \\
\hline $\mathrm{mmolOH}^{-} \cdot \mathrm{g}^{-1}$ & $0.942^{* *}$ & 0.666 & $0.744^{*}$ & $-0.865^{* *}$ & 1 & $-0.725^{*}$ & $-0.689^{*}$ & $0.933^{* *}$ \\
\hline$\% \mathrm{H}$ & $-0.908^{* * *}$ & $-0.973^{* *}$ & $-0.992^{* *}$ & $0.885^{* *}$ & $-0.725^{*}$ & 1 & 0.068 & $-0.806^{* *}$ \\
\hline$\% \mathrm{TOC}$ & -0.445 & 0.057 & -0.066 & 0.384 & $-0.689^{*}$ & 0.068 & 1 & -0.514 \\
\hline $\mathrm{CEC}\left(\mathrm{mmol} \cdot \mathrm{kg}^{-1}\right)$ & $0.946^{* *}$ & $0.745^{*}$ & $0.820^{* *}$ & $-0.867^{* *}$ & $0.933^{* *}$ & $-0.806^{* *}$ & -0.514 & 1 \\
\hline
\end{tabular}

** The correlation is significant at $0.01 ; *$ The correlation is significant at 0.05

In other words, as the pyrolysis temperature increases, the number of $\mathrm{H}^{+}$on the biochar's surface decreases correspondingly to the range of 5.1-3.7 $\mathrm{mmolH}^{+} \cdot \mathrm{g}^{-1}$. The decrease in $\mathrm{mmolH}^{+} \cdot \mathrm{g}^{-1}$ was statistically significant at 300 and $600^{\circ} \mathrm{C}$ while the increase in $\mathrm{mmolOH}^{-}$was significant at all three temperatures. This observation matched the conclusion reached by Mukherjee et al.(2011) [17]and Yang et al el.(2019)[18]in regard to biochar originating from plant. The CEC of biochar increased to $113-188 \mathrm{mmol} . \mathrm{kg}^{-1}$ when the pyrolysis temperature increased.

Correlation analysis showed that pyrolysis temperature is proportional and strongly correlated to surface-level chemical characteristics of the biochar samples such as $\mathrm{mmol} \mathrm{OH}^{-}, \mathrm{pH}_{\mathrm{pzc}}$, and $\mathrm{pH}$ (Table 2). Moreover, it also showed that the inverse oportionality between pyrolysis temperature and mmol $\mathrm{H}^{+}$(as well as recovery efficiency) is strongly correlated while that between temperature and TOC is weakly correlated. TOC has almost no correlation with other factors except for a moderate downhill relationship with $\mathrm{OH}^{-}$. Meanwhile, $\mathrm{CEC}$ has a positive relationship with pyrolysis temperature.

FTIR spectroscopy was used to determine functional groups in biochar samples. The results from the analysis on a FT/IR-4700 type A spectrometer (Figure 1), showed a peak at 3500$3000 \mathrm{~cm}^{-1}$ for biochar produced at $300^{\circ} \mathrm{C}$. This suggests the presence of a large $-\mathrm{OH}$ functional groups[19]. -OH group gradually decreases for

\subsection{Effect of pyrolysis temperature on $\mathrm{Cd}^{2+}$ adsorption equilibrium of biochar}

The investigation of $\mathrm{Cd}^{2+}$ adsorption equilibrium of three biochar samplesproduced at different pyrolysis temperatures $\left(300,450\right.$ and $\left.600^{\circ} \mathrm{C}\right)$ showed that the adsorption capacity rises in proportion to the initial biochar produced at 450 and $600^{\circ} \mathrm{C}$. The peak at 1590-1520 $\mathrm{cm}^{-1}$ happened due to COO- bonds. The spectra's intensity here is reduced when the temperature increases. The peak at 1160-1020 $\mathrm{cm}^{-1}$ is speculated to be caused by the vibration of $\mathrm{C}-\mathrm{O}-\mathrm{C}$ bonds of polysaccharide or carbonate $\left(\mathrm{CO}_{3}{ }^{2-}\right)$ compounds[16]. These bonds are formed when the temperature increases.Figure 1 matches the conclusion of a previous study, which suggests that biochar produced at high pyrolysis temperatures are characterized by strong carboncarbon bonds and have high stability as a result of their aromatic hydrocarbons qualities[20]. The appearance of the peak at $2311 \mathrm{~cm}^{-1}$ in biochar produced at 450 and $600^{\circ} \mathrm{C}$ is speculated to be caused by the vibration of $\mathrm{C} \equiv \mathrm{C}$ bonds or by carbon dioxide.

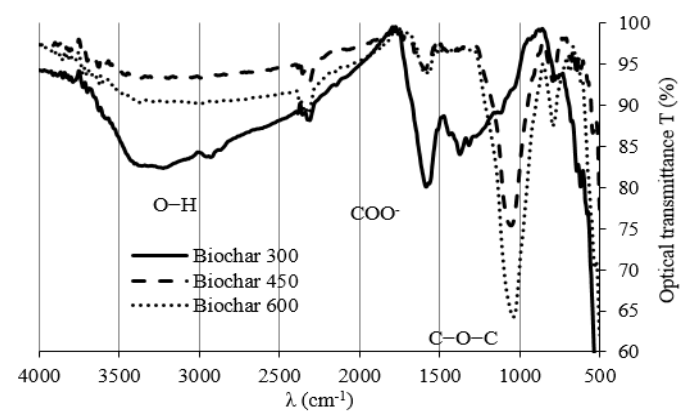

Figure 1: FTIR spectra of biochar produced from pyrolysis at 300,450 and $600^{\circ} \mathrm{C}$

concentration $\mathrm{C}_{0}$ of $\mathrm{Cd}^{2+}$ regardless of the pyrolysis temperature. In specific, when $\mathrm{C}_{0}$ increases from 0 to $132 \mathrm{mgCd}^{2+} . \mathrm{L}^{-1}$, the adsorption capacity rises to 5.3, 4.6, 5.6 mg. $\mathrm{g}^{-1}$, respectively and has reached saturated adsorption state (Figure 2). 
Nguyen Van Phuong et al., International Journal of Emerging Trends in Engineering Research, 9(3), March 2021, 203 - 210 Biochar at $300^{\circ} \mathrm{C}$ Biochar at $450^{\circ} \mathrm{C}$
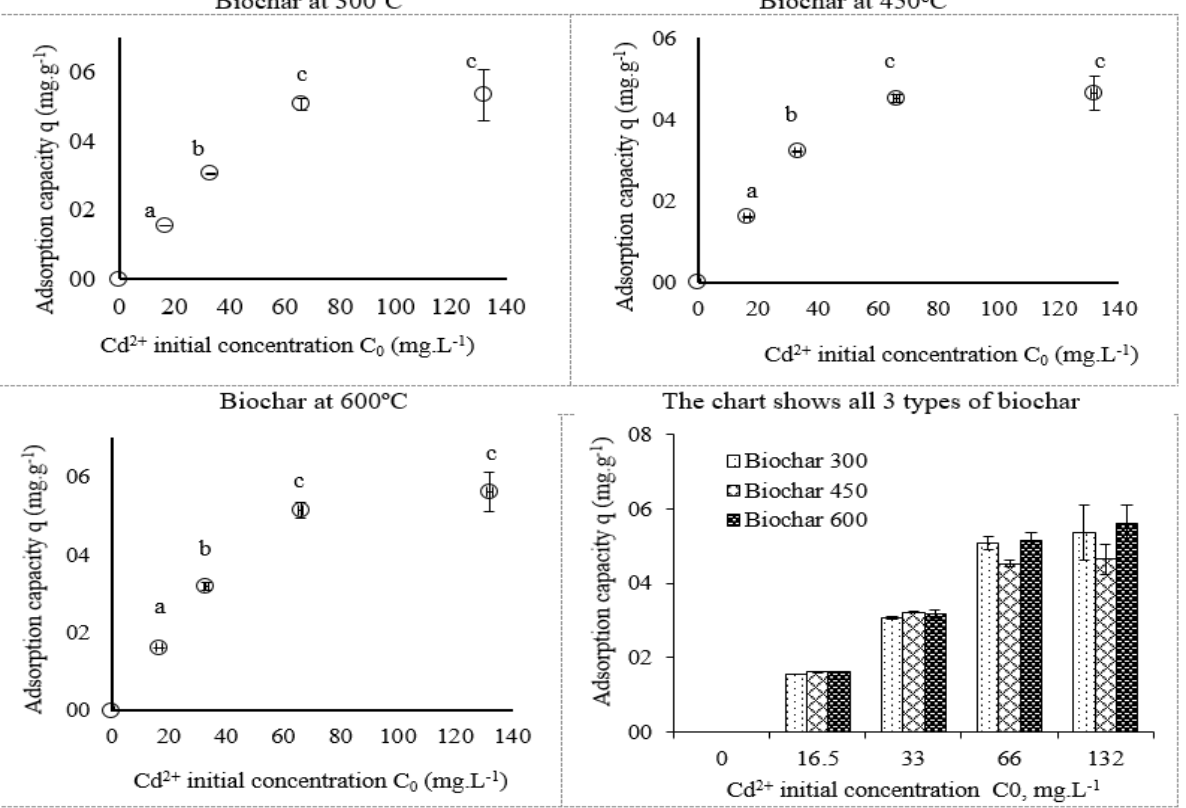

Figure 1: Adsorption capacity $\mathrm{Cd}^{2+}\left(\mathrm{mg} \cdot \mathrm{g}^{-1}\right)$ vs $\mathrm{Co}\left(\mathrm{mg}_{\mathrm{L}} \mathrm{L}^{-1}\right)$ at different pyrolytic temperatures. Different letters represent statistically significant differences

The calculated parameters for an adsorption isotherm equation yielded a good fit for Langmuir's model with the Chi-square $\mathrm{R}^{2}$ values 0.99 , 0.93 , and 0.96 respectively. The maximum adsorption capacity was calculated to be $5.81,5.12$ and $5.88 \mathrm{mg}^{-\mathrm{g}^{-1}}$ respectively and these values approximated the data gathered from experiments. The result indicated that the $\mathrm{Cd}^{2+}$ adsorption on the biochar's surface is homogeneous in terms of energy. Experimental data also matched Freundlich's model with the Chi-square correlation value $\mathrm{R}^{2}$ ranged from 0.83 to 0.91 (Table $3)$. In addition, the Freundlich isotherm constant $n_{F}$ representing adsorption intensity (also known as surface heterogeneity) and the degree of adsorption in this study are calculated to be greater than 1 , with the values of $3.86,6.25,4.67$ respectively for the three biochar samples. As $\mathrm{n}_{\mathrm{F}}>1$ indicates high adsorption[21], this means these three samples are highly adsorptive of $\mathrm{Cd}^{2+}$ given the experiment's conditions.According to $\mathrm{Xu}$ et al. (2013), the adsorption of metal ions in solutions are influenced by surface-level chemical characteristics and precipitation-inducing reactions. Furthermore, a study by Han et al. (2017)[22] suggested that the presence of electrostatic adsorption and functional groups might also be a factor in $\mathrm{Cd}^{2+}$ adsorption. The experimental results in this study indicated the presence of functional groups such as $-\mathrm{COOH}$ and $\mathrm{OH}$ on the surface of biochar samples (Table 1 and Figure 1) and, as these functional groups can interact with $\mathrm{Cd}^{2+}$ to create complex or precipitation on the surface, they might indeed play a role in $\mathrm{Cd}^{2+}$ adsorption equilibrium.

In addition to adsorption by electrostatic interactions, adsorption by $\mathrm{O}-\mathrm{H}$ bonds was also confirmed by FT/IR-4700 type A spectrometer (Figure 1) analyses. Specifically, biochar produced at $300^{\circ} \mathrm{C}$ exhibited this form of adsorption the strongest as the $\mathrm{O}-\mathrm{H}$ bonds that create complexes within the solution are converted to weaker $\mathrm{C}-\mathrm{O}$ bonds at $450^{\circ} \mathrm{C}$. As C-O-C bonds are weaker, the maximum adsorption capacity $\mathrm{q}_{0}$ is also reduced accordingly Xu et al., (2013)[10].

However, the adsorption capacity increased again with biochar produced at $600^{\circ} \mathrm{C}$. This is consistent with q of experimentof the study by Kolodynska et al. (2012)[11], which found biochar originating from cow dung has better $\mathrm{Cd}^{2}+$ adsorption when produced at $600^{\circ} \mathrm{C}$ than when produced at $400^{\circ} \mathrm{C}$. It is speculated that this increase was caused by the increase in $\mathrm{pH}$ level, which in turn promotes precipitation on the biochar's surface (Figure 1). It is shown in this study that the maximum $\mathrm{Cd}^{2+}$ adsorption capacity of these three biochar samples ranged from 5.12 to $5.88 \mathrm{mg} . \mathrm{g}^{-1}$. This is much lower than the result of Kołodynska et al. (2012), in which the value ranged from 49.06 to $51.28 \mathrm{mg}^{-1}{ }^{-1}$. This can be explained by the lower initial concentration in this study (0-132 mg. $\left.\mathrm{L}^{-1}\right)$ compared to the study of Kolodynska et al. (2012) (112-2800 mg.L ${ }^{-1}$ ) where hydrolytic precipitation processes had occurred and changed the adsorption capacity[11] 
Table3:Parameters of $\mathrm{Cd}^{2}+$ adsorption isotherm models

\begin{tabular}{|c|c|c|c|c|c|}
\hline Models & $\begin{array}{l}\text { Pyrolytic } \\
\text { temperature }\end{array}$ & \multicolumn{2}{|c|}{ Parameters } & $\mathrm{R}^{2}$ & $\begin{array}{c}\text { qmax }_{\max } \text { of experiment, } \\
\text { mg.g } \mathrm{g}^{-1}\end{array}$ \\
\hline \multirow{3}{*}{ Langmuir } & Biochar $300^{\circ} \mathrm{C}$ & $\mathrm{q}_{0}\left(\mathrm{mg} \mathrm{g}^{-1}\right)=5.81$ & $\mathrm{~K}_{\mathrm{L}}=0.44$ & 0.99 & 5.3 \\
\hline & Biochar $450^{\circ} \mathrm{C}$ & $\mathrm{q}_{0}\left(\mathrm{mg} \cdot \mathrm{g}^{-1}\right)=5.12$ & $\mathrm{~K}_{\mathrm{L}}=1.67$ & 0.93 & 4.6 \\
\hline & Biochar $600^{\circ} \mathrm{C}$ & $\mathrm{q}_{0}\left(\mathrm{mg} \mathrm{g}^{-1}\right)=5.88$ & $\mathrm{~K}_{\mathrm{L}}=1.46$ & 0.96 & 5.6 \\
\hline \multirow{3}{*}{ Freundlich } & Biochar $300^{\circ} \mathrm{C}$ & $\mathrm{n}_{\mathrm{F}}=3.86$ & $\mathrm{~K}_{\mathrm{F}}=2.05$ & 0.83 & 5.3 \\
\hline & Biochar $450^{\circ} \mathrm{C}$ & $\mathrm{n}_{\mathrm{F}}=6.25$ & $\mathrm{~K}_{\mathrm{F}}=2.54$ & 0.91 & 4.6 \\
\hline & Biochar $600^{\circ} \mathrm{C}$ & $\mathrm{n}_{\mathrm{F}}=4.67$ & $\mathrm{~K}_{\mathrm{F}}=2.55$ & 0.89 & 5.6 \\
\hline
\end{tabular}

3.3.Effect of pyrolysis temperature on $\mathrm{Cd}^{2+}$ adsorption kinetic of biochar

$\mathrm{Cd}^{2+}$ adsorption increased sharply in a first hour for allthree biochar samples produced at $300,450,600^{\circ} \mathrm{C}$ (Figure 3). After that, the adsorption process slowed down and reached equilibrium after $2 \mathrm{~h}$ from the start of the experiment. The absorption capacity $\mathrm{q}_{\mathrm{t}}$ reached 53.2, 79.2, and $77.7 \%$ in the first $15 \mathrm{~min}$ and the adsorption capacity at equilibrium $\mathrm{q}_{\mathrm{e}}$ is achieved at 93.1, 94.1, and 90.7\% in $2 \mathrm{~h}$ respectively. In addition, the varianceof $\mathrm{Cd}^{2+}$ adsorption capacities at equilibrium after $2 \mathrm{~h}$ indicated no statistical significance between the three biochar samples (Figure 3).

One-way ANOVA on the adsorption kinetic using a pseudo first-order model (Table 4) showed that the correlation coefficientsR ${ }^{2}$ fell in the rangefrom 0.83 to 0.99 . However, the calculated $\mathrm{q}_{\mathrm{e}}$ did not match the experimental value; the calculated $\mathrm{q}_{\mathrm{e}}$ values for the three biochar samples were 1.84, 1.98, and 0.94 $\mathrm{mg} \cdot \mathrm{g}^{-1}$ while the experimental values were found to
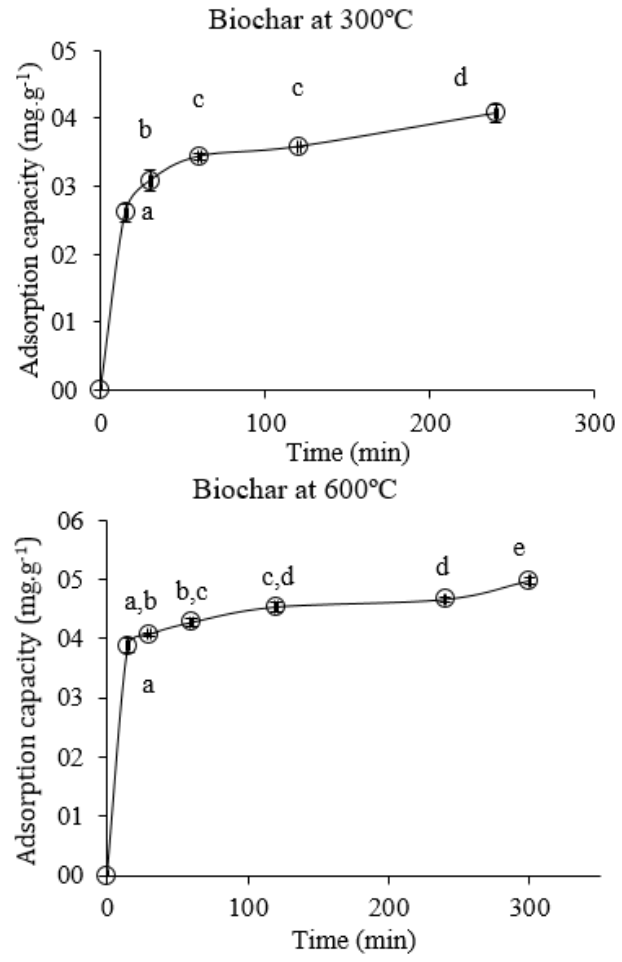

be $4.8,4.9$, and $5.0 \mathrm{mg} \cdot \mathrm{g}^{-1}$, respectively. Therefore, it is safe to conclude that the pseudo first-order model was not suitable for explaining theCd ${ }^{2+}$ adsorption kinetic of the biochars in this research. This result wasidentical to that of Kołodynska et al. (2012), which also demonstrated that the pseudo first-order model was not suitable due to the difference between the calculated and experimental values[11].On the other hand, one-way ANOVA on the adsorption kinetic using a pseudo second-order model (Table 4) yielded a strong correlation $\left(\mathrm{R}^{2}\right.$ coefficients $\left.0.8-0.95\right)$ and the calculated $\mathrm{q}_{\mathrm{e}}$ matched that from the experiments. Hence, it was concluded that the pseudo second-order kinetic model appropriately explained $\mathrm{Cd}^{2+}$ adsorption kinetic of the biochar samples in this research.That means the kinetic process isinfluenced by thechemical adsorption[11],[23]. The value of $\mathrm{k}_{2}$ increased slightly from 0.013 to $0.072 \mathrm{~g} \cdot \mathrm{mg}^{-1} \cdot \mathrm{min}^{-}$ ${ }^{1}$ when the pyrolysis temperature increased from 300 to $600^{\circ} \mathrm{C}$, indicating a faster adsorption rate [11].

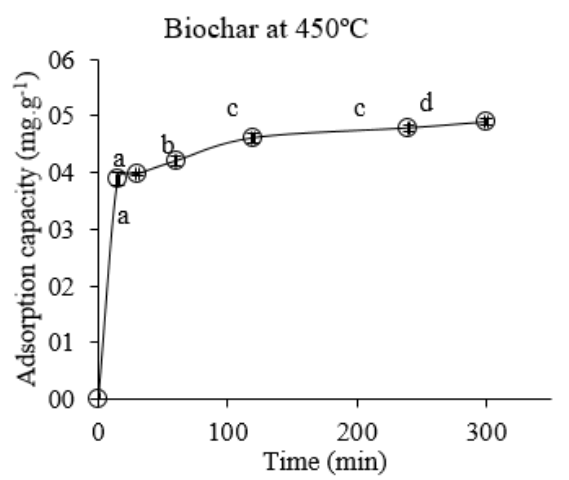

Adsorption efficiency of 3 forms of biochar

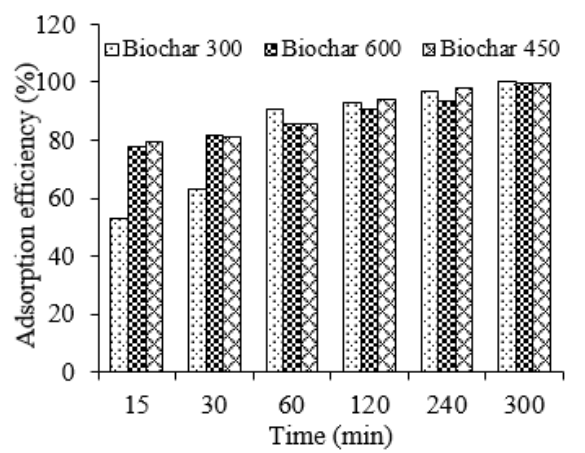

Figure2: Effect of the contact time on $\mathrm{Cd}^{2+}$ adsorption of the biochar forms. Different letters represent statistically significant differences 
Table4:Parameters of $\mathrm{Cd}^{2}+$ adsorption kinetic on biochar

\begin{tabular}{|c|c|c|c|c|c|}
\hline Models & $\begin{array}{c}\text { Pyrolytic } \\
\text { temperature }\end{array}$ & $\underset{1)}{\mathrm{q}_{\mathrm{e}}(\mathrm{mg} \cdot \mathrm{g}}$ & Kinetic constant & $\begin{array}{c}\text { qe of experiment. } \\
\text { mg.g-1 }\end{array}$ & $\mathrm{R}^{2}$ \\
\hline \multirow{3}{*}{$\begin{array}{l}\text { Pseudo first- } \\
\text { order }\end{array}$} & Biochar $300^{\circ} \mathrm{C}$ & 1.84 & $\mathrm{k}_{1}\left(1 \cdot \min ^{-1}\right)=0.012$ & 4.8 & 0.83 \\
\hline & Biochar $450^{\circ} \mathrm{C}$ & 1.58 & $\mathrm{k}_{1}\left(1 \min ^{-1}\right)=0.015$ & 4.9 & 0.91 \\
\hline & Biochar $600^{\circ} \mathrm{C}$ & 0.94 & $\mathrm{k}_{1}\left(1 \mathrm{~min}^{-1}\right)=0.013$ & 5.0 & 0.99 \\
\hline \multirow{3}{*}{$\begin{array}{l}\text { Pseudo } \\
\text { second-order }\end{array}$} & Biochar $300^{\circ} \mathrm{C}$ & 5.11 & $\mathrm{k}_{2}\left(\mathrm{~g} \cdot \mathrm{mg}^{-1} \cdot \mathrm{min}^{-1}\right)=0.013$ & 4.8 & 0.95 \\
\hline & Biochar $450^{\circ} \mathrm{C}$ & 4.73 & $\mathrm{k}_{2}\left(\mathrm{~g} \mathrm{mg}^{-1} \cdot \mathrm{min}^{-1}\right)=0.055$ & 4.9 & 0.8 \\
\hline & Biochar $600^{\circ} \mathrm{C}$ & 4.60 & $\mathrm{k}_{2}\left(\mathrm{~g}_{\mathrm{mg}} \mathrm{I}^{-1} \cdot \mathrm{min}^{-1}\right)=0.072$ & 5.0 & 0.9 \\
\hline
\end{tabular}

\section{CONCLUSION}

In general, the temperature at which the biochar was pyrolyzed has a strong proportional correlation with the biochar's surface-level chemical characteristics such as mmolOH, $\mathrm{pH}_{\mathrm{pzc}}, \mathrm{pH}, \mathrm{CEC}$ and a weak proportional correlation with TOC. The maximum $\mathrm{Cd}^{2+}$ adsorption capacities at pyrolysis temperatures 300,450 and $600^{\circ} \mathrm{C}$ were determined to be as follows: $5.81,5.12,5.88 \mathrm{mg} \cdot \mathrm{g}^{-1}$. Both Langmuir and

\section{REFERENCES}

[1] Z. Zhou, Z. Xu, Q. Feng, D. Yao and J. Yu, "Effect of pyrolysis condition on theadsorption mechanism of lead, cadmium and copper on tobacco stem biochar," Journal of Cleaner Production, vol. 187, pp. 126, 2018.

[2] Chen, Z., Zhang, J., Huang, L., Yuan, Z., Li, Z., Liu, M., "Removal of $\mathbf{C d}$ and $\mathbf{P b}$ withbiochar made from dairy manure at low temperature," Journal of Integrative Agriculture, vol. 18(, no. 1, pp. 201-210. https://doi.org/10.1016/S2095-3119(18)619872, 2019.

[3] H. N. Tran, S.-J. You and H.-P. Chao, "Effect of pyrolysis temperatures and times on the adsorption of cadmium onto orange peel derived biochar," Waste Management \& Research, vol. 34, no. 2, p. 129 -138, 2016.

[4] N. V. Phuong, N. T. C. Nhung and L. T. M. Ngoc, "Equilibrium and kinetic of copper adsorption on livestock waste derived biochar," Journal of Food Science and Technology, vol. 18, no. 2, pp. 78-88, 2019.

[5] G. Yoo, H. Kim, J. Chen and Y. Kim, "Effects of Biochar Addition on Nitrogen Leaching and Soil Structure following Fertilizer Application to Rice Paddy Soil," Soil Science Society of America Journal, vol. 78, no. 3, pp. 852-861, 2014.

[6] T. T. Tu, "Physical and chemical characterization of biochar derived from rice husk," Journal of Science - Hue university, vol. 120, no. 6, pp. 233-247, 2016.

[7] TCVN 8941, "Soil quality Determination of total organic carbon -
Freundlich adsorption isotherm models matched the observed $\mathrm{Cd}^{2+}$ adsorption process in the experiments. A pseudo second-order model is sufficient in representing the $\mathrm{Cd}^{2+}$ adsorption process.Based on the aforementioned results, the biochar produced from cow dungis viable as an adsorbent for $\mathrm{Cd}^{2+}$ removal from water and the pyrolysis temperature of the biochar production has a negligible impact on the adsorption capacity of biochar.

Walkley Black method," Ministry of natural resource and environment, 2011.

[8] W. Cheung, S. Lau, S. Leung, A. Ip and G. McKay, "Characteristics of Chemical Modified Activated Carbons from Bamboo Scaffolding," Chinese Journal of Chemical Engineering, vol. 20, no. 3, pp. 515-523, 2012.

[9] ISO 11260, "Soil quality - Determination of effective cation exchange capacity and base saturation level using barium chloride solution.," ISO, 1994.

[10] X. Xu, X. Cao, L. Zhao and H. Wang, "Removal of $\mathrm{Cu}, \mathrm{Zn}$, and $\mathrm{Cd}$ from aqueous solutions by the dairy manure-derived biochar," Environ Sci Pollut Res, vol. 20, p. 358-368, 2013.

[11] D. Kołodynska, R. Wnetrzak, J. Leahy, H. M.H.B., W. Kwapinski and Z. Hubicki, "Kinetic and adsorptive characterization of biochar in metal ions removal," Chemical Engineering Journal, vol. 197, p. 295-305, 2012.

[12] J. Xie, X. Sun, D. Yang and R. Cao, "Combined toxicity of cadmium and lead on early life stages of the Pacific oyster, Crassostrea gigas," ISJ - Invertebrate Survival Journal, vol. 14, pp. 210-220, 2017.

[13] S. Joseph, C. Peacocke, J. Lehmann and P. Munroe, Biochar for Environmental Management: Science and Technology, J. Lehmann and S. Joseph, Eds., London: Earthscan, 2009.

[14] S. Yavari, A. Malakahmad and N. B. Sapari, "Effects of production conditions on yield and physicochemical properties of biochars produced from rice husk and oil palm empty fruit bunches," Environmental 
Science and Pollution Research, vol. 23, no. 18, pp. 1-13, 2016.

[15] M.-E. Lee, J. H. Park and J. W. Chungg, "Adsorption of $\mathrm{Pb}(\mathrm{II})$ and $\mathrm{Cu}(\mathrm{II})$ by Ginkgo-Leaf-Derived Biochar Produced under Various Carbonization Temperatures and Times," Int J Environ Res Public Health, vol. 12, p. 14, 2017.

[16] Y. Ding, Y. Liu, S.liu, Z. Li, X. Tan, X. Huang, G. Zeng, Y. Zhou, B. Zheng and X. Cai, "Competitive removal of $\mathrm{Cd}$ (II) and $\mathrm{Pb}$ (II) by biochars produced from water hyacinths: performance and mechanism," RSC Advances, pp. 1-28, 2016.

[17] Mukherjee, A., Zimmerman, A.R., Harris, W., "Surface chemistry variations among a series of laboratory-produced biochars," Geoderma, pp. 163(3-4), 247-255., 2011.

[18] X. Yang, S. Zhang, M. Ju and L. Liu, "Preparation and Modification of Biochar Materials and their Application in Soil Remediation," Applied Sciences, pp. 2-25, 2019.

[19] Y. K. Kiran, A. Barkat, C. Xiao-qiang, F. Ying, P. Feng-shan, T. Lin and Y. X. -e, "Cow manure and cow manure-derived biochar application as a soil amendment for reducing cadmium availability and accumulation by Brassicachinensis $L$. in acidic red soil," Journal of Integrative Agriculture, vol. 16, no. 3, p. 725-734, 2017.

[20] B. Singh, M. C. Arbestain and J. Lehmann,
Biochar : a guide to analytical methods, B. Singh, M. Camps-Arbestain and J. Lehmann, Eds., CRC Press/Taylor and Francis Group, LLC, 2017.

[21] A. Khalil, N. Sergeevich and V. Borisova, "Removal of ammonium from fish farms by biochar obtained from rice straw: Isotherm and kinetic studies for ammonium adsorption," Adsorption Science \& Technology, vol. 36, no. 5-6, pp. 1294-1309, 2018.

[22] L. Han, H. Sun, K. S. Ro, K. Sun and J. A. Libra, "Removal of antimony (III) and cadmium (II) from aqueous solution using animal manure-derived hydrochars and pyrochars," Bioresource Technology, vol. 234, pp. 77-85, 2017.

[23] X. Cui, Y. Yao, S. Fang and T. Li, "Potential mechanisms of cadmium removal from aqueous solution by Canna indica derived biochar," Science of The Total Environment, vol. 562, no. 15, pp. 517-525, 2016. 